1. To be reviewed for possible publication in this journal all authors must follow the instructions below and submit their manuscript to:

Dr Robyn Gillies, School of Education

The University of Queensland

Brisbane QLD 4072, Australia

All articles are refereed. Papers submitted to the journal must not previously have been published nor submitted for publication to any other journal.

2. Contributions should follow the general style described in the Publication Manual of the American Psychological Association, (5th ed., 2001), except that spelling should conform to The Macquarie Dictionary (3rd ed. rev.). For matters of style not covered in these two publications the Style Manual for Authors, Editors and Printers (6th ed., Wiley) should be consulted.

3. A computer disk (PC or Mac), together with an original (and two anonymous copies for referees), should be submitted. Material on the disk should correspond exactly to the printout. It should be doublespaced, on one side of A4 paper, with minimum margins of $20 \mathrm{~mm}$ on the left and $35 \mathrm{~mm}$ on the right. Uncommon abbreviations should be explained. On no account should anything be underlined unless it is desired that it be printed in italics. Full stops should not be used in abbreviations or contractions (e.g. NSW). A word count should be provided.

4. Under the title of the article only the names of the authors appear. Qualifications, present appointments, and postal and email addresses should be given as a separate first page.

5. Tables should be printed at the end of the manuscript (not in the main text) and included on the disk. Their approximate positions in the text should be indicated by the words: "Table X about here". Horizontal and vertical lines should be used sparingly. Figures should be supplied as hard copy only unless they can be provided in Adobe Illustrator, EPS or TIFF formats. They should be presented as Laser or photographic bromide output at a minimum print density of $600 \mathrm{dpi}$ and should not include shaded areas of grey, but instead use repeated patterns of lines or crosses to distinguish for example different bars on a graph. Print outs should be included after the tables, and their approximate positions also indicated in the text as above. The figures should be preceded by a page listing figure numbers and titles and should be numbered on the back with figure number, title of article and name of author(s).

6. Use double quotation marks to introduce a word or phrase used as an ironic comment, as slang, or as an invented or coined expression. Use quotation marks for the first time the word or phrase is used; thereafter, do not use quotation marks. Do not use double quotation marks to introduce a technical or key term. Instead, underline the term.

7. Do not use any footnotes. Endnotes should be kept to a minimum and listed at the end of the text under the centred heading 'NOTES'. Acknowledgements should be placed at the end of the article with a separate heading.

8. References should follow the Publication Manual of the American Psychological Association (5th ed., 2001). Examples of citations are:

The theory was first propounded in 1970 (Larsen, 1971).

Larsen (1970) was the first to propound the theory.

Examples of references are:

Fisse, B. (1989). The proceeds of the Crime Act: The rise of money laundering, offences and the fall of principle. Criminal Law Journal, 13, 5-23.

Zelinski, E.M., \& Gilewski, M.J. (1988). Memory for prose and aging: A metaanalysis. In M.L. Howe \& C.J. Brainerd (Eds.), Cognitive development in adulthood (pp. 133-158). New York, NY: Springer-Verlag.

9. Authors are expected to check the accuracy of all references in the manuscript before submission. It may not be possible to submit proofs for correction.

10. While manuscripts are subject to editing, the Australian Guidance Counselling Association does not hold itself responsible for statements made by contributors.

11. Copyright of articles published in this journal ordinarily remains vested in the authors. The Executive, however, reserves the right to grant permission for reproduction of excerpts on special occasions such as specific teaching use with limited circulation or where it is not possible to contact authors. 


\section{Australian Journal of}

\section{Guidance and Counselling}

\section{Editorial}

Robyn Gillies

\section{Articles}

Positive Statements, Positive Students, Positive Classrooms

Paul C. Burnett

School Mental Health Promotion - Theoretical, Conceptual and Practical Issues

Louise Rowling

Broadening Social Networks for Girls and Particularly for Boys:

Outcomes of a Coping Skills Program

Neringa Luscombe Smith, Erica Frydenberg and Charles Poole

The Friendly Schools Project: An Empirically Grounded

School-based Bullying Prevention Program

Donna Cross, Yolanda Pintabona, Margaret Hall, Greg Hamilton, Erin Erceg and Clare Roberts

Prevention and Intervention for Anxiety Disorders

in Children and Adolescents: A Whole School Approach

Marilyn A. Campbell

Building Depression Resilience in Adolescents: A 2-year Evaluation of the Resourceful Adolescent Program (RAP)

in a South West Sydney High School

Pandora Petrovski, Stephen Matthey and Leanne Clarke

Why School Counsellors and Psychologists Should

Treat Addiction Problems

Nadine Pelling

"But I'm Not Really Bad": Using an Idiographic Versus

a Nomothetic Approach to Understand the Reasons

for Difficult Behaviour in Children

Vicki Bitsika

Children of Parents with a Mental Illness

- The COPMI Project

Elizabeth Fudge 